\title{
Nexus between food, energy, water, and forest ecosystems in the USA
}

\author{
Thomas L. Tidwell ${ }^{1}$
}

Published online: 26 February 2016

(C) The Author(s) 2016. This article is published with open access at Springerlink.com

\begin{abstract}
Efforts to promote appreciation for the multifaceted contributions of forests are particularly timely because of the many threats currently faced by forests. These threats include the world's growing population, which is projected to top 9.1 billion by 2050; global climate change; land degradation; land scarcity; and deforestation. Already, human activities have destroyed $50 \%$ of the forests that once existed under modern climatic conditions. The US Forest Service's research and management activities are promoting the health, productivity, and resilience of forests and grasslands by, for example, advancing agroforestry, producing and applying science and technology that integrates energy production into sustainable forest and grassland management practices, and protecting water supplies by increasing the quality of aquatic habitats, reducing erosion, and decreasing peak flows. The US Forest Service must increase public understanding and support for such efforts to restore and create healthy landscapes that will supply vital resources to future generations.
\end{abstract}

Keywords Forestry · Energy · Agriculture · Water resources · Climate change

\section{Introduction}

As long as human beings have been on Earth, they have been modifying the environment and impacting ecosystems. They

Thomas L. Tidwell ttidwell@fs.fed.us

1 US Forest Service, 201 14th Street SW, 4 NW, Washington, DC 20024, USA have done so through varied activities including hunting, farming, building shelters, breeding and caring for animals, generating energy, and harvesting forests for timber and fuel. Human life is deeply dependent on an enormous variety of organisms whose life cycles require specific environmental conditions. These environmental conditions are disturbed by varied types of anthropogenic disturbances.

Largely because of these activities and the expansion of populated areas, about half of the forests that were present under modern (i.e., post-Pleistocene) climatic conditions have disappeared (UNEP-WCMC 1998). What is more, almost two thirds of the world's forests currently show clear signs of past human interventions, according to the Food and Agriculture Organization of the United Nations (FAO) (2014).

According to Lambin and Meyfroidt (2011), land use change is a major driver of global environmental change. They pointed out that from 1980 to 2000, more than half of the new agricultural land across the tropics came at the expense of intact forests and another $28 \%$ came from disturbed forests, raising concerns about environmental services and biotic diversity globally. Nevertheless, the causes and timing of forest losses and current trends in changes in forest cover differ among regions and forest types (FAO 2014).

Forests are one of the most important ecosystems on Earth. They are the origin of many sources of food, medicines, raw materials for construction, water, energy, and wild plants domesticated into critically important crops. Forests today show clear signs of past human interventions. Agricultural expansion has come largely at the expense of forest ecosystems. Deforestation associated with the expansion of crops, pasture, and human development has resulted in large biological diversity losses.

Many important relationships exist between the health and productivity of forests, the services and products they provide, and varied types of ongoing environmental changes. 
In the USA, sustaining and enhancing healthy and productive ecosystems that will provide goods and services to current and future generations requires developing options for strategically managing natural resources. This requires increasing the understanding and raising the awareness of the complex and controversial nexus between food, water, energy, and forests.

\section{Water nexus}

One of the greatest challenges our nation is facing-and, indeed, the world - is water.

The conservation challenges the USA and the rest of the world face run the gamut, from increasing intensity of wildfires to invasive species, to a growing human population, and to all the associated demands on forests.

Water is the most important natural resource. It is essential to sustaining people, agriculture, industry, and ecosystems. Few forces are more important than water in shaping the human condition. Water is a central organizer of ecosystems. Water shapes the physical landscape and governs its vegetation, laying the very basis for human life and civilization. Water is critical to life: without it, humans have no hope for food and raw material security.

The Earth has 13.63 billion ha of surface land area (FAO 2012a), which equals $29.2 \%$ of its total surface area; $70.2 \%$ of its surface area is covered by water. The oceans contain $97 \%$ of our planet's available water. The remaining $3 \%$ of available water is in the Earth's atmosphere, on the terrestrial surface, and in various forms and stores in the lithosphere (Pidwirny 2006). About $97.5 \%$ of the Earth's water is saline; the remaining $2.5 \%$ is freshwater. Most freshwater-about $68.7 \%$ - is present as ice in ice caps and glaciers (Perlman 2014)

Water scarcity affects roughly 1 to 2 billion people worldwide. Up to $25 \%$ of global freshwater use exceeds sustainable supplies, and global water quality is deteriorating. By 2025, $40 \%$ of the world's population could be living in water-scarce regions, especially as the climate changes (Millennium Ecosystem Assessment 2005b). The Millennium Ecosystem Assessment (2005a) indicated that during the next 50 years, demand for food crops is projected to grow by 70 to $85 \%$ under the Millennium Ecosystem Assessment scenarios, and demand for water by between 30 and $85 \%$. Water withdrawals in developing countries are projected to increase significantly under the scenarios, although these are projected to decline in industrialized countries.

A source of concern is that much of the world is facing likely water shortages, and these shortages will be exacerbated in the future because of climate change, population growth, forest fragmentation, and urbanization. The United Nations World Water Assessment Programme (WAPP) (2015) states that by 2050 , agriculture will need to produce $60 \%$ more food globally and $100 \%$ more in developing countries. In addition, FAO (2012a) reported that since about $70 \%$ of all the water withdrawn for human use goes for agriculture, there is a concern that water scarcity will affect the future of food production. Serious water shortages appear likely to arise differentially among localities, regions, and countries.

FAO (2012a) has also indicated that irrigation is crucial to the world's food supplies. From 1997 to 1999, irrigated land made up only about one fifth of the total arable area in developing countries but produced two fifths of all crops and close to three fifths of cereal production. The role of irrigation is expected to increase still further. The developing countries as a whole are likely to expand their irrigated area from 202 million ha from 1997 to 1999 up to 242 million ha by 2030 . Most of this expansion will occur in land-scarce areas where irrigation is already crucial.

FAO (2012a) has also concluded that the net increase in irrigated land is predicted to be less than $40 \%$ of that achieved since the early 1960s. There appears to be enough unused irrigable land to meet future needs: FAO studies suggest a total irrigation potential of some 402 million ha in developing countries, of which only half is currently in use. According to WAPP (2015), current growth rates of global agricultural water demand are unsustainable; the sector will need to increase its water use efficiency by reducing water losses.

A challenge in achieving food security will be the development, assessment, and deployment of technologies, crops, and varieties that will sustainably increase the production of food per unit area while minimizing excessive use of water and other agricultural supplies such as insecticides and fertilizers that could negatively impact other ecosystem services. This indicates a major role for research in developing crops, cropping systems, and farming and ranching practices that increase water and nutrient use efficiency.

Global annual water withdrawal is approximately $3600 \mathrm{~km}^{3}$ per year or $25 \%$ of the continental runoff. In addition, 4 out of every 5 people live downstream of, and are served by, renewable freshwater services, representing $75 \%$ of the total supply (Millennium Ecosystem Assessment 2005b).

It is in this context that forest ecosystems are critically important, because according to the Millennium Ecosystem Assessment (2005b), forest and mountain ecosystems serve as source areas for the largest amounts of renewable freshwater supply-57 and $28 \%$ of total runoff, respectively. These ecosystems each provide renewable water supplies for at least 4 billion people or two thirds of the global population. Cultivated and urban ecosystems generate only 16 and $0.2 \%$, respectively, of global runoff, but because of their close proximity to human settlements, they serve 4 to 5 billion people. Such proximity is also associated with nutrient and industrial water pollution. 
Areas covered with vegetation are the main supply for water collection, from which streams, rivers, springs, and subterranean and superficial bodies of water are fed. When land use changes from more to less pervious surfaces or vegetation is lost in an uncontrolled manner, e.g., wildfire, insect per disease damage, or illegal logging, the ability of the system to retain and deliver water is negatively affected. The role of forests in interception, infiltration, and evapotranspiration, which, as a group, define the movement of the water and its storage in the soil, is very important (Waring and Schlesinger 1985). The forested land absorbs rain, refills underground aquifers, cools and cleanses water, slows storm runoff, reduces flooding, sustains watershed stability and resilience, and provides critical habitat for fish and wildlife. In addition to these ecological services, forests provide abundant water-based recreation and other benefits that improve the quality of life (Sedell et al. 2000). Forest lands can be managed to enhance both water quality and quantity (Marion et al. 2014).

The USA faces an increasingly large set of water resource challenges as water shortages and water use conflicts become more commonplace (Alley et al. 2013). Forests and water are connected, as foresters, conservationists, and natural resource managers have long been understood. Fifty-three percent of the nation's surface water supply originates on forest land, even though forests cover just $29 \%$ of the nation's surface area (Furniss et al. 2010). Public and private forest lands combined furnish water supplies for more than 180 million Americans.

The national forests and grasslands - the lands that are managed by the US Forest Service - were established by the Forest Service Organic Administration Act of 1897 (U.S. Congress 1897), which provided the main statutory basis for the management of forest reserves in the USA. The national forests are the single most important source of water in the country. These lands have over 400,000 miles of streams and over 3.5 million acres of lakes and wetlands, and over half of the nation's hydroelectric power supplies in the contiguous USA come from the national forests alone. That is a value estimated at $\$ 3.7$ billion per year. These lands furnish drinking water to about 60 million Americans living in about 3400 communities, including great cities like Atlanta, Georgia; Denver, Colorado; and Portland, Oregon. In a sense, the US Forest Service is the nation's largest water company. For more than a hundred years, a critical part of our mission has been sustaining the health of our nation's forests to protect the quantity and quality of our nation's water supply.

Much of the country has been in prolonged drought; the outlook for this summer again is for persistent drought, from Montana and Oregon down to the Mexican border and from the California coast to the central Great Plains. It is tempting to think of drought as temporary, but in an era of climate change, that is wishful thinking. One expert put it this way: "You can't call it a drought anymore, because it's going over to a drier climate. No one says the Sahara is in drought."

Climate change aside, the past century is not a reasonable guide to the future for water management. Over the past 100 years, population and water infrastructure have rapidly grown across the west during a period that was much wetter than the long-term average. Now, we could be entering a much drier period in the west, more in line with the long-term average over the past 1200 years. People need to understand that so we can be prepared.

In an era of climate change, the US Forest Service is taking steps with partners to protect the nation's water sources by

- Restoring and protecting riparian forests to reduce stream temperatures and increase the quality of aquatic habitats.

- Improving or decommissioning roads to reduce erosion, increase flood plain connectivity, decrease peak flows, and reduce temperature impacts.

- Restoring meadows, wetlands, and flood plains to improve ecological continuity, increase water storage, reduce flood flows, and raise late summer flows.

- Restoring and maintaining persistently wet places as biological oases for watershed resilience and for aquatic species.

- Removing migration barriers and reestablishing habitat connectivity to help species adapt to changing conditions.

- Strategically reducing wildfire risks in watersheds vulnerable to excessive erosion, stream temperature increases, and other impacts.

The Farm Bill requires the states to identify landscapes critical to the future of conservation. Based in part on the results, the US Forest Service is working with the states and other partners to protect and restore a series of landscapes that are valuable, vulnerable, and amenable to collaborative planning and management.

A good example of this type of collaborative planning and management by the US Forest Service is the work in the Chesapeake Bay drainage, which covers much of the mid-Atlantic region. It is well known that the health of the bay is threatened by development and resource overexploitation. The US Forest Service has long collaborated with EPA and other public and private partners on efforts to restore the Chesapeake Bay. The US Forest Service manages 1.4 million acres of the national forest land in the watershed, protecting the quality of the water that flows into the bay. The US Forest Service also uses its authorities to work through state and municipal partners to protect and restore ecosystems in the watershed, partly by planting urban trees, improving forest management on private land, and acquiring conservation easements for sensitive lands at risk of development. 
Forests are a key to water purification and delivery, and the US Forest Service has a long history of protecting watersheds. But climate change has created a whole new environment for land and resource management. The US Forest Service is working to restore healthy, resilient ecosystems capable of delivering clean water and all the other ecosystem services that Americans want and need.

\section{Food nexus}

Against this backdrop of increasing world population and environmental change, the global community is challenged to conserve the Earth's limited resources and fragile ecosystems while enhancing the production of food and other goods and services. Global agriculture is pressured by various factors, such as land degradation, shortages of agricultural land, and the conversion of farmland to non-agricultural land.

Roberts (2011) pointed out that in 1900, there were 1.6 billion people on Earth and that in 2000, this figure had reached 6.1 billion. Although the rate of world population growth has slowed and varies substantially by region, it is still increasing. According to FAO (2014), the world's current population of 7.2 billion is projected to reach 9.6 billion by 2050. Along with population growth, the demand for energy and wood products for both industrial and domestic uses is expected to increase by $40 \%$ in the next 20 years. The demand for other forest-related goods (food, medicine, fodder, and other commodities) is also predicted to increase. FAO (2014) also indicates that a major consequence of population pressure is land use change with forest conversion to crop and pasture land; this together with overexploitation, selective harvesting, and high tree mortality due to extreme climatic events can result in local species extinctions and the loss of forest genetic resources.

According to FAO (2012a), the world may be heading towards shortages of suitable agricultural land: in some regions and areas, there are already serious shortages and these may worsen. FAO studies indicated that less new agricultural land will be opened up than in the past. Over the period from 1961 to 1999 , the expansion of arable land in developing countries totaled 172 million ha. FAO forecasts indicate that in the next 30 years, an increase of only 120 million ha, or $13 \%$, will be required. This means adding an extra 3.75 million ha per year which is less than the rate of 4.8 million ha per year that occurred in the second half of the last century.

According to FAO (2012a), there is potential agricultural land that is as yet unused. At present, some 1.5 billion ha of land is used for crops, around $11 \%$ of the world's surface area. However, much of this potential land is in practice unavailable or locked up in other valuable uses. Some $45 \%$ is covered in forests, $12 \%$ is in protected areas, and $3 \%$ is taken up by human settlements and infrastructure. In addition, much of this land may have characteristics that make agriculture difficult, such as low soil fertility and lack of infrastructure among other problems. The tendency towards land scarcity associated with population growth is aggravated by the conversion of farmland to urban uses, land degradation, and other factors.

In many countries, much farmland is being converted to non-agricultural uses. FAO (2012a), assuming a requirement for housing and other infrastructures of 40 ha per 1000 people, concludes that the world population growth between 1995 and 2030 implies the need for an additional 100 million ha of land. Since most urban centers are sited on or near fertile agricultural land in coastal plains or river valleys, their expansion takes up more of this prime land. Despite these projected losses, there is little evidence to suggest that global land scarcities lie ahead.

Although land scarcity and the problems associated with it will likely continue at country and local levels, FAO (2012a) also indicated that during the last 40 years of the last century, world cropland grew by only $11 \%$ while world population almost doubled. As a result, cropland per person fell by $40 \%$, from 0.43 ha to only 0.26 ha. Yet, over this same period, nutrition levels improved considerably and the real price of food declined. This was explained by increases in agricultural productivity decreasing land needed for growing food of approximately $56 \%$ over this same period.

Perhaps the most important factor to consider that could imply land scarcity will be land degradation. Land degradation occurs when soil's current or future capacity to produce is lowered by chemical, physical, or biological changes. It has also been defined as a long-term decline in ecosystem function and measured in terms of net primary productivity (Bai et al. 2008).

A global assessment of land degradation and improvement (Bai et al. 2008) identified $24 \%$ of land as degrading in addition to the $15 \%$ assessed as degraded by the global assessment of land degradation in the 1990s (Oldeman et al. 1991). This means that new areas are being affected. This indicates potential food production problems in places with the highest amounts of degraded land, which are mainly in Africa, south of the Equator, Southeast Asia, South China, North Central Australia, the Pampas, and swaths of boreal forest in Siberian and North America (Bai et al. 2008).

Forest ecosystems and forest cover are critically important in maintaining soil and water that support sustainable agriculture; providing habitats for the biological interactions that maintain crops, livestock, and wildlife; and mitigating impacts of climate change and extreme weather events at the landscape scale as well other disturbances such as flooding. This connection indicates the important role that forest ecosystems play in food security for people in many countries.

Trees and forests contribute in many ways to improving the diet and decreasing hunger for local communities and the rural 
population. Forests are sources of food and medicines, help increase incomes, and improve the agricultural production through soil protection and water provision. According to Bhaskar et al. (2015), close to one of every six persons on the planet directly depend on forests and food is the main element of this dependence. In addition, Bhaskar et al. (2015) indicates that forests and tree-based systems have played a major role throughout human history, supporting livelihoods and helping to meet food security and nutritional needs of the global population.

The food originating from forests offers security against hunger cases of seasonal food shortages or in states of emergency caused by catastrophic events such as droughts, floods, or wars. In many countries, it is common for people to gather wild food from the forests including meat and wild edible mushrooms, especially when conventional agricultural crops are unavailable. Women in some regions consider forest resources as a source of supplementary nutrition in addition to an emergency food source and as a cooking fuel supply. In many instances, forests and trees are used to maintain domestic nutritional standards when other food products cannot be purchased or produced in large quantities in the community.

According to the Millennium Ecosystem Assessment (2005a), 17 countries found that $22 \%$ of household income for rural communities in forested regions comes from sources typically not included in national statistics, such as harvesting wild food, fuelwood, fodder, medicinal plants, and timber. In the USA, native community members and rural dwellers hunt meat and gather fruits, herbs, and edible mushrooms as part of their diet.

In many developing countries, forests contribute in many ways to the well-being of local populations, because forests are a great source of biodiversity supporting people's food security, nutrition, and health (Ruiz and Arnold 1996; Mohamed-Katerere and Smith 2013). Arnold et al. (2011) mentioned that forests provide a diversity of healthy foods high in micronutrients and fiber and low in sodium, refined sugar, and fat; products from forests are often culturally valued, are integral to local food systems and food security, and help households fill seasonal and other cyclical food gaps, acting as a safety net or buffer in times of shortages due to drought, crop failure, illness, or other emergencies.

In addition to land scarcity and land degradation, the challenge of feeding a growing population in the future is the impact of deforestation. According to FAO (2014), the rate of loss of forest cover - mainly from conversion of tropical forest to agricultural land - shows signs of decreasing but is still alarmingly high. Around 13 million ha of forest was converted to other uses or lost through natural causes each year between 2000 and 2010, compared with 16 million ha per year in the 1990s.

Deforestation is expected to slow further in the coming decades, and the world is unlikely to face a wood supply crisis
(FAO 2012b). Production of wood-based materials is continually increasing in efficiency. An important impact of deforestation and land use change is on biodiversity. Life on Earth depends on healthy and productive ecosystems with a diverse composition of plants, animals, and other organisms, which are essential for food and other benefits and services for humans. The main impact of deforestation is on the loss of intraspecific diversity in economically important species with consequences not only for immediate agriculture seed supply and forestry but also in terms of reduced opportunities for selection and breeding for resistance to diseases and insect attack.

Many authors agree that biological diversity is the foundation of agriculture and forestry systems, pharmaceutical products, aesthetics, recreation and spiritual value, evolutionary processes, stabilization of ecosystems, environmental quality, and intrinsic worth of all species on Earth. Approximately $90 \%$ of the world food for people comes from just 15 plant species and 8 animal species, and several thousand other plant species are used as food by humans (cited by Pimentel et al. 1992).

Pimm et al. (1995) have indicated that we do not know the amount of species existing on Earth. They pointed out that only approximately 10 million species are described and less than 100,000 terrestrial vertebrates, some flowering plants, and invertebrates are popular enough to be known well. They suggest that most species are as yet undescribed in every species-rich group.

Pimentel et al. (1997) indicated that in the USA, there are an estimated 750,000 species, of which small organisms, such as arthropods and microbes, make up $95 \%$. The USA is one of the 12 countries that, as a group, have between 60 and $70 \%$ of the total biodiversity in the planet. In this context, the USA is considered a mega diverse country (Mittermeier and Goettsch 1992).

Many rural areas in the USA still maintain the custom of having family orchards that produce additional food. One example in the USA is Sealaska, which owns and manages 30, 000 acres near Kake, Alaska. The corporation manages the forest for timber as well as wildlife and understory plants so that its shareholders - all tribal members - can hunt, fish, and gather. This helps them meet their local food needs while also providing economic opportunities. In 2012, prices for wild organic blueberries topped $\$ 3.10$ per pound, with demand for food and value-added health products, nutraceuticals, and wine, and tribal members harvested the berries for personal use and sold some of the surplus. Some earned more than $\$ 600$ per day from the harvest - a significant wage in a town where the per capita income is just over $\$ 22,000$ per year. Selling these wild berries as organic means that not only they were not sprayed with chemicals, but they are also an indigenous species carefully and sustainably managed with other forest products. 
Other examples of forest farming are shiitake mushroom production in Vermont; the establishment of riparian buffers with several different native tree species to help conserve soil, protect the riparian area from sediment erosion, and shade the stream to increase a salmon habitat in Washington State; the production of hazelnuts, hickory nuts, and walnuts in Ohio; and the establishment of silvopasture systems in the Southern United States among many other examples (USDA, National Agroforestry Center 2015).

The US Forest Service is one of 17 agencies in the US Department of Agriculture. The other 16 agencies are primarily focused on food, agricultural commodities, livestock, and nutrition. It is therefore not hard to see how the agenda within the department is dominated by the concerns of agricultural commodities and production. When the topic of food security is discussed, it is normally a dialogue about agricultural productivity and nutrition monitoring, but now has shifted to a more long-term vision for ecosystem health and its contribution to food security.

One of the ways the US Department of Agriculture has strived to recognize the beneficial relationship between trees and agriculture is by advancing agroforestry. "Agroforestry isn't conversion of agricultural lands to forests; rather, it is using trees in support of agriculture." There are five widely recognized categories of agroforestry practices in the USA: alley cropping, forest farming, riparian forest buffers, silvopasture, and windbreaks. In addition to making agricultural lands more resilient to climate change, agroforestry helps farmers and ranchers meet increasing demands for food, energy, and conservation while providing an array of other services like clean water, soil conservation, wildlife habitat, and feedstocks for producing renewable energy.

For example, in the Southeastern United States, farmers and ranchers are establishing silvopastures where they manage trees, livestock, and forage together in a system that yields multiple crops and income streams annually from livestock and longer term from high-value sawlogs, supplemented by periodic harvest of pine straw, valuable landscaping mulch. The trees, in turn, provide shade that is critical to reducing heat stress in livestock during the hot summers in that region.

Since the early 1990s, much of the US Department of Agriculture work to advance agroforestry has been carried out by its National Agroforestry Center, a cross-agency collaboration between the US Forest Service and the Natural Resources Conservation Service, another agency in the US Department of Agriculture. In 2011, our department released an agroforestry strategic framework, which is now the agroforestry roadmap for all agencies in the US Department of Agriculture. As a result of this new cross-agency collaboration, the 2012 US Department of Agriculture's Census of Agriculture, a questionnaire completed by all agricultural producers every 5 years, has the first-ever agroforestry question. The responses to this question will help to gain critical information about the demographics of producers who have adopted agroforestry.

The future lies in creating much more cross-sectoral collaboration of this kind, where the aim is not competition, but integrated and sustainable land use systems across landscapes. Planning needs to become more cross-sectoral in nature, and bureaucracies need to find ways to structure themselves to quickly respond to and engage on a range of emerging issues. And therein lies one of the central challenges for forests and forestry today. It is the challenge of persuading others that the returns from standing and working forestsincluding working trees on agricultural lands - are worth the cost of investing in them.

So, the US Forest Service needs to find better ways to make that case. The US Forest Service needs to make a compelling case that working forests are a cornerstone of long-term community prosperity, including food security. The US Forest Service must manage resilient landscapes for multiple uses, considering all lands that combine food production, biodiversity conservation, other land uses, and the provision of ecosystem services to achieve food security.

\section{Energy nexus}

The relationships between food, energy, water, and forests are inextricably linked and have been since the beginning of humankind. Until petroleum became widely available about 100 years ago, wood was the most important energy source together with coal (U.S. Department of Energy 2013). Wood continues to be the primary source of energy for heating and cooking in many of the world's poorest countries (FAO 2008). Arnold et al. (2003) indicated that until the middle of the nineteenth century, wood was the main source of energy even in North America and Europe and that it has been replaced by more efficient, cheaper, and convenient sources of fuel such as coal, charcoal, oil, and gas. In industrialized countries, particularly those with large wood processing industries, wood energy is often used in significant amounts for both domestic and industrial purposes.

Continuing energy security and greenhouse gas emission concerns are driving research, development, and deployment of sustainable biofuels, biopower, and bioproducts. Forest lands play an important role in these efforts. Analyses by the International Energy Agency (IEA) (2011) show that biofuels are expected to play an important role in the long term as the world transitions away from fossil fuels. Advanced biofuels can provide infrastructure-compatible, low-carbon fuels and are expected to have higher land use efficiency and better greenhouse gas balance than some first-generation biofuels (IEA 2011). The IEA (2012) analyses also show that biomass, including wood, will play an increasingly important role in heat and power production. Co-firing biomass in coal-fired 
plants provides an opportunity for short-term and direct reduction of emissions, and biomass heat and electricity are competitive with fossil fuels depending on conversion efficiencies and supply chain costs (2012). This can potentially benefit farmers and forest owners and support rural development. Biomass feedstocks in the form of wood pellets are being traded globally.

While forest lands provide wood, an increasingly important global energy source, they are also important sources of fossil energy (oil, natural gas, and coal), hydropower, and geothermal energy. In addition, energy transmission corridors cross forest lands. the continued use of wood as a conventional source of energy in developing countries, the advances in science and technology to produce biofuels and biopowers from forest and agriculture feedstocks, and the role of forest lands in supplying renewable and fossil energy have created a complex nexus between food, energy, water, and the environment. In this context, the US Forest Service's role is to effectively contribute to the sustainable development and use of energy resources for present and future generations through land management, technical and financial assistance, research and development, and energy conservation while maintaining and enhancing overall environmental quality, sustainability, and economic opportunities (USDA Forest Service 2011).

Historically, energy contributions of the US Forest Service included the subsistence use of fuel wood from National Forest System lands for communities and railroads. Special use administration of National Forest System lands has facilitated energy rights-of-way for power transmission and fuel pipelines, hydroelectric development in forest watersheds, and private development of energy resource deposits beneath National Forest System lands. Research on wood chemistry has contributed to the scientific understanding needed to produce cellulosic biofuels, while research on silviculture, timber harvest and collection, and transportation has provided scientific knowledge for sustainable production and utilization of forest biomass for energy (USDA Forest Service 2011).

Blanco et al. (2013) pointed out that the use of agricultural products as a feedstock for biofuel production is growing rapidly in many countries primarily due to market forces and policy support. The aims of increasing energy security and reducing greenhouse gas emissions in the transport sector have encouraged many countries to establish policies to promote biofuels. As a result of these policy measures, as well as fluctuating fossil fuel prices, biomass and biofuel markets are expected to grow substantially in the coming decades. Global production of biofuels has been growing steadily over the last decade from 16 billion 1 in 2000 to more than 100 billion 1 in 2011. Today (on an energy basis), biofuels provide around $3.5 \%$ of the total road transport fuel globally and substantially higher fractions in some countries (IEA 2013).

The Organization for Economic Cooperation and Development (OECD 2012) indicated that currently, some
$65 \%$ of EU vegetable oil, $50 \%$ of Brazilian sugarcane, and about $40 \%$ of corn production in the USA are being used as a feedstock for biofuel production. The OECD (2012) projected that by $2021,14 \%$ of global coarse grain production will be used to produce ethanol, the sugarcane-based share of global ethanol production is projected to be $28 \%$, cellulosics will account for almost $9.5 \%$ of ethanol, and the share of biodiesel produced from vegetable oil is expected to be $16 \%$. The OECD (2012)-projected scenario is that based on their greater potential to increase land devoted to agriculture and to improve productivity, developing countries will provide the main source of global production growth to 2021 .

Moreover, according to WAPP (2014), biomass can be used to produce a range of fuels that can be used for heating, power generation, and transport. Bioenergy investments can generate profits for investors and growers, create jobs, improve livelihoods, and increase economic opportunities in rural areas.

In 2014, the USA exported 4.4 million short tons of wood pellets primarily for generating electricity in the European Union (U.S. Energy Information Administration 2015), mostly from the Southern United States. The main driver for growing wood pellet consumption in Europe is the European Commission's 2020 climate and energy plan. This plan (European Commission 2010) aims to reduce greenhouse gas emissions and increase the contribution of renewable to total energy consumption in the European Union.

Concerns have been raised regarding both the greenhouse gas emissions associated with wood energy as well as the potential impact on forest systems associated with the emerging pellet industry. Recent research examining 930 scenarios for wood pellets found relative savings in GHG emissions for wood pellets with respect to a unit of electricity derived from fossil fuels in the UK to range between 50 and $68 \%$, depending upon the capacity of power plant and rotation age (Dwivedi et al. 2014). Results from western studies show emission benefits from using wood from hazardous fuel treatments for energy production (Jones et al. 2010; Loeffler and Anderson 2014). Studies have also consistently found that demand for wood products, including specifically wood pellets, actually serves to maintain or increase the amount of land in forests (Abt et al. 2014; Galik and Abt 2015), especially in those privately owned small forests, in which best forest management practices have been applied, and those that produce wood and woody biomass for energy under certified forest management plans. The US Forest Service continues research in these areas to quantify outcomes and ensure sustainable systems.

Biomass energy is creating markets in areas where they did not previously exist for small or defective trees. These new markets help achieve a variety of forest management and sustainability goals: wildfire mitigation, forest health, restoration, watershed improvements, wildlife habitat, timber stand 
improvement, aesthetics, and more. These goals are particularly important as climate change and invasive species lead to increased mortality in the nation's forests.

The agricultural sector is the largest user of water resources, accounting for roughly $70 \%$ of all freshwater withdrawals globally and over $90 \%$ in most of the world's leastdeveloped countries (WWAP 2014). Freshwater withdrawals for energy production, which currently account for $15 \%$ of the world's total (WWAP 2014), could increase by $20 \%$ through 2035. Practices like efficient irrigation techniques and developing and deploying more water use-efficient varieties can have a dramatic impact on reducing water demand, especially in rural areas. Many of the pressures that impact water supply and use occur at local and national levels and are influenced by rules and processes established at those levels. Increasingly, however, the rules and processes that govern global economics-investment of capital, trade, financial markets, as well as international aid and development assistance - influence local and national economies and policies.

Woody biomass is a renewable material that can be used to produce power, heat, and liquid fuels (Buford and Neary 2010). The real value of forest biomass for energy production is its renewability and potential sustainability; woody biomass from forests can be harvested and then grown again in a sustainable manner. They also noted that forestlands are expected to meet a long list of demands beyond energy production, including the production of water, wood, and non-wood products. Humans also rely on these areas for many other services such as recreation and habitat. We are also beginning to understand the value of forests, forest management, forest products, and avoiding emissions from substituting wood bioenergy and bioproducts for fossil-intensive products in a carbon management strategy. Healthy, productive, and resilient forests are an important facet of climate change mitigation.

The nation's forests are strategic assets that help the USA achieve energy security, economic opportunity, environmental quality, and global competitiveness by providing a raw material for the renewable wood energy and wood product markets. These markets are a growing source of jobs, particularly in rural America, that contribute to a sustainable future based on a locally grown renewable resource. From a land management and restoration perspective, expanding biomass, wood products, and wood energy markets reduces forest treatment costs, reduces wildfire risk, restores forested landscapes, and generates new income streams for forest landowners.

Forests and energy are linked. The US Forest Service is taking steps with partners to

- Contribute to national energy security, environmental quality, and economic opportunities through sustainable land management, energy production, and conservation.
- Produce, acquire, disseminate, and effectively use science and technology to integrate energy production into sustainable forest and grassland management.

- Identify federal agencies and non-federal partners and collaboratively work to optimize overall federal energy results in the context of sustainable natural resource management.

- Promote and provide problem-solving, energy awareness, sustainable resource conservation, and energy-related assistance to states, tribes, and local communities.

For more than a century, the US Forest Service has contributed to the nation's energy supply. As the nation designs and implements a new energy future that addresses climate change and ensures energy security, the US Forest Service - through management of national forest system lands; state, tribal, and private landowner assistance programs; and development and transfer of new science, technology, and decision support tools - will proactively contribute to sustainable production of renewable and non-renewable energy, energy transmission and distribution, and increased forest service energy efficiency.

\section{Conclusion}

\section{Informing and engaging the public}

One of the key responsibilities of the US Forest Service is to inform the public and policymakers about the value of forests and their contributions to the nation's economy, environment, and society. The most important role of a forestry agency is to make sure that this message is effectively and consistently communicated outside of the forestry community and to build support for the sustainable management of forests.

This document indicates the points of view of many authors about the important role forests play in providing sources of food, clean and abundant water, energy, forest products, and economic activity that sustain and enhance communities and the nation. All this is well understood in the forestry community. Indeed, the US Forest Service has heard it all over the country. The importance of forests is rarely questioned even outside the forestry community.

However, the true measure of how clearly this message is understood is what the society is actually willing to support in terms of the land use decisions that are made and related budgets that are passed as well as forest management decisions and investments made by private landowners. These policy- and market-based decisions are largely made outside the forestry community.

As methods of natural accounting continue to develop, they will help citizens and policymakers to better understand the value of forests to the countries' economies and long-term 
sustainability. Researchers have started to measure such values in economic terms. The US Forest Service is among a number of entities in the USA that are conducting or sponsoring such studies. Specifically, the US Forest Service is interested in determining the full value of ecosystem services from the lands it manages, the national forests, and grasslands. These lands comprise an enormous area of 37 million ha all across the USA.

America's forests, grasslands, and other open spaces are integral to the social, ecological, and economic well-being of the nation. The US Forest Service plays a vital role in providing public benefits and services such as clean air, clean water, minerals and energy, and fertile soils for supporting timber, forage, carbon storage, food and fiber, fish and wildlife habitat, and opportunities for outdoor recreation. We deliver a valuable service to the public by restoring and improving forest, grassland, and watershed health; producing new knowledge through our research; and providing financial and technical assistance to partners, including private forest landowners.

The concepts of ecosystem service flows and natural capital stocks are increasingly useful ways to highlight, measure, and value the degree of interdependence between humans and the rest of nature. Estimates of the global accounting value of ecosystem services expressed in monetary units are mainly useful to raise awareness about the magnitude of these services relative to other services provided by human-built capital at the current point in time. Estimates show that global land use changes between 1997 and 2011 have resulted in a loss of ecosystem services of between $\$ 4.3$ and $\$ 20.2$ trillion per year, being these estimates conservative (Costanza et al. 2014). Now, this is only an estimate. Nevertheless, this huge amount does give some idea of the enormous value that people get from the ecosystem services they derive from their forest ecosystems.

These steps are also good for jobs and the economy. In the nation's national forests, the emphasis has been on restoration activities, such as timber harvests to thin stands to restore forest resiliency, healthy conditions, and watersheds. Between 26 and 33 million ha of the national forest system in the USA needs restoration, while at the same time, budgets are flat or declining. But through increased efficiencies in planning, the US Forest Service is increasing the area restored each year.

Just as important, the US Forest Service is generating jobs. One study has shown that every million dollars spent on restoration activities generate 12 to 28 jobs, which compares favorably to most other economic activities (Moseley and Nielson-Pincus 2009). Restoration is not only good for the environment but also for communities' livelihoods, which is directly connected to their ability to provide for their own food security.
The US Forest Service can and will do more, but it cannot succeed alone. Success will require a series of collective endeavors - coalitions of organizations and individuals working collaboratively across broad geographic areas, with the full knowledge and support of the American people. In these hard economic times, forestry organizations cannot hope to secure resources without making a convincing case about the benefits to people's livelihood that result from working on forests and from working forests.

Working together across borders and boundaries, we have an opportunity to make a difference, even in an era of climate change. Through landscape-scale conservation, we can restore, enhance, and create healthy, resilient landscapes capable of supplying the resources the American people want and need for generations to come.

Open Access This article is distributed under the terms of the Creative Commons Attribution 4.0 International License (http:// creativecommons.org/licenses/by/4.0/), which permits unrestricted use, distribution, and reproduction in any medium, provided you give appropriate credit to the original author(s) and the source, provide a link to the Creative Commons license, and indicate if changes were made.

\section{References}

Abt KL, Abt RC, Galik CS, Skog KE (2014) Effect of policies on pellet production and forests in the U.S. South: a technical document supporting the U.S. Forest Service update of the 2010 RPA Assessment. Gen. Tech. Rep. SRS-202, Asheville, NC: U.S. Department of Agriculture U.S. Forest Service, Southern Research Station. http://www.treesearch.fs.fed.us/pubs/47281. Accessed 9 July 2015

Alley WM, Evenson EJ, Barber NL, Bruce BW, Dennehy KF, Freeman MC, Freeman WO, Fischer JM, Hughes WB, Kennen JG, Kiang JE, Maloney KO, Musgrove Mary Lynn, Ralston Barbara, Tessler Steven, Verdin JP (2013) Progress toward establishing a national assessment of water availability and use: U.S. Geological Survey Circular 1384

Arnold M, Kholin G, Persson R, Shepperd G (2003) Fuelwood revisited: what has changed in the last decade? Occasional Paper No. 39. Center for International Forestry Research. Jakarta, Indonesia p 35

Arnold M, Powell B, Shanley P, Sunderland TCH (2011) Forests, biodiversity and food security. Int For Rev 13(3):259-264, Commonwealth Forestry Association

Bai ZG, Dent DL, Olsson L, Schaepman ME (2008) Global assessment of land degradation and improvement. 1. Identification by remote sensing. Report 2008 per 01, ISRIC - World Soil Information, Wageningen, Netherlands

Bhaskar V, Wildburger C, Stephanie M (eds.) (2015) Forests, trees and landscapes for food security and nutrition. A global assessment report. IUFRO World Series Volume 33. Vienna, Austria

Blanco M, Adenäuer M, Shrestha S, Becker A (2013). Methodology to assess EU biofuel policies: the CAPRI approach. Scientific and Policy Report by the Joint Research Centre of the European Commission

Buford AM, Neary, DG (2010) Sustainable biofuels from forests: meeting the challenge. Biofuels and Sustainability Reports. Ecological Society of America 
Costanza R, de Groot R, Sutton P, van der Ploeg S, Anderson Sharolyn J, Kubiszewski I, Farber S, Turner Kerry R (2014) Changes in the global value of ecosystem services. Glob Environ Chang 26:152-158

Dwivedi Puneet, Khanna Madhu, Bailis Robert, Ghilard Adrian (2014) Potential greenhouse gas benefits of transatlantic wood pellet trade. Environ. Res. Lett. 9 024007. http://iopscience.iop.org/1748-9326/ 9/2/024007/metrics. Accessed 8 July 2015

European Commission (2010) Communication from the commission to the European Parliament, the Council, the European Economic and Social Committee and the Committee of the Regions: Energy 2020 - a strategy for competitive, sustainable and secure energy. COM/2010/0639 final http://eur-lex.europa.eu/legal-content/EN/ TXT/?qid=1409650806265\&uri=CELEX:52010DC0639

Food and Agriculture Organization of the United Nations (2008) Forests and energy. Key issues. FAO Forestry Paper 154. Rome, Italy. ftp:// ftp.fao.org/docrep/fao/010/i0139e/i0139e00.pdf. Accessed 7 July 2015

Food and Agriculture Organization of the United Nations (2012a) World agriculture towards 2030-2050 - summary report. Rome, Italy

Food and Agriculture Organization of the United Nations (2012b) State of the world's forests. Rome, Italy. http://www.fao.org/docrep/016/ i3010e/i3010e.pdf. Accessed 7 July 2015

Food and Agriculture Organization of the United Nations (2014) The state of the world's forest genetic resources. Rome, Italy. http:// www.fao.org/3/a-i3825e.pdf. Accessed 28 December 2015

Furniss Michael J, Staab Brian P, Hazelhurst Sherry, Clifton Cathrine F, Roby Kenneth B, Ilhadrt Bonnie L, Larry Elizabeth B, Todd Albert H, Reid Leslie M, Hines Sarah J, Bennett Karen A, Luce Charles H, Edwards Pamela J (2010) Water, climate change, and forests: watershed stewardship for a changing climate. Gen. Tech. Rep. PNW-GTR-812. Portland, OR: U.S. Department of Agriculture, U.S. Forest Service, Pacific Northwest Research Station

Galik CS, Abt RC (2015) Sustainability guidelines and forest market response: an assessment of European Union pellet demand in the Southeastern United States. GCB Bioenergy. doi: 10.1111 per gcbb. 12273

International Energy Agency (2011) Technology roadmap - biofuels for transport. Paris, France: OECD/IEA. https://www.iea.org/ publications/freepublications/publication/Biofuels_Roadmap_ WEB.pdf. Accessed July 82015

International Energy Agency (2012) Technology roadmap-bioenergy for heat and power. Paris, France: OECD/IEA. https://www.iea. org/publications/freepublications/publication/2012 Bioenergy Roadmap_2nd_Edition_WEB.pdf. Accessed 8 July 2012

Jones G, Loeffler D, Butler E, Chung W, Hummel S (2010) Emissions, energy return and economics from utilizing forest residues for thermal energy compared to onsite pile burning. In: Jain Theresa B, Graham Russell T, Sandquist Jonathan (eds): Integrated management of carbon sequestration and biomass utilization opportunities in a changing climate. Proceedings of the 2009 National silviculture workshop; 2009 June 15-18; Boise, ID. Proceedings RMRS-P-61. Fort Collins, CO: U.S. Department of Agriculture, U.S. Forest Service, Rocky Mountain Research Station pp 145-153. http: per per www.treesearch.fs.fed.us per pubs per 37319. Accessed 9 July 2015

Lambin EF, Meyfroidt P (2011) Global land use change, economic globalization, and the looming land scarcity. Proc. Natl Acad Sci U.S. 108: 3465-3472

Loeffler D, Anderson N (2014) Emissions tradeoffs associated with cofiring forest biomass with coal: a case study in Colorado, USA. Appl Energy 113:67-77

Marion Daniel A, Sun Ge, Caldwell Peter V, Miniat Chelcy F, Ouyang Ying, Amatya Devendra M, Clinton Barton D, Conrads Paul A, Gull Laird Shelby, Dai Zhaohua, Clingenpeel J, Alan, Liu Yongqiang, Roehl Edwin A Jr, Moore Myers Jennifer A, Trettin Carl (2014)
Managing forest water quantity and quality under climate change. In: Vose James M, Klepzig Kier D (eds) Climate change adaptation and mitigation management options: a guide for natural resource managers in southern forest ecosystems. Boca Raton, FL: CRC Press. 249-305. http://www.treesearch.fs.fed.us/pubs/45792. Accessed 9 July 2015

Millennium Ecosystem Assessment (2005a) Ecosystems and human well-being: synthesis. Island, Washington

Millennium Ecosystem Assessment (2005b) Chapter 7: fresh water. Island, Washington

Mittermeier R, Goettsch C (1992) La importancia de la diversidad biológica de México. En: Sarukhán JyR. Dirzo (comps.). México ante los retos de la biodiversidad. Conabio, México

Mohamed-Katerere J, Smith M (2013) The role of ecosystems in food security. Unasylva 64, 2013 per 2: 14-22

Moseley C, and Nielson-Pincus M (2009) Economic impact and job creation from forest and watershed restoration: a preliminary assessment. (Ecosystem Workforce Program Briefing Paper \#14; winter 2009; Institute for Sustainable Development, Eugene, OR). http:// ewp.uoregon.edu/sites/ewp2.uoregon.edu/files/downloads/BP14. pdf. Accessed 30 December 2015

OECD/FAO (2012) OECD-FAO Agricultural outlook 2012-2021. OECD Publishing and FAO. http://dx.doi.org/10.1787/agr outlook-2012-en. Accessed 4 July 2015

Oldeman LR, RTA Hakkeling, WG Sombroek (1991) World map of the status of human-induced soil degradation, 2nd edition. ISRIC, Wageningen, Netherlands

Perlman H (2014) The world's water. USGS Water-Science School. Retrieved 22 May 2015

Pidwirny M (2006) Introduction to the oceans. Fundamentals of physical geography, 2nd edition. http: per per www.physicalgeography.net per fundamentals per 8o.html. Accessed 22 May 2015

Pimentel D, Stachow U, Takacs DA, Brubaker HW, Dumas AR, Meaney JJ, O’Neil JAS, Onsi DE, Corzilius DB (1992) Conserving biological diversity in agricultural forestry systems. Bioscience 42:354362

Pimentel D, Wilson C, McCullum C, Huang R, Dwen P, Flack J, Tran Q, Saltman T, Cliff B (1997) Economic and environmental benefits of biodiversity. Bioscience 47:747-757

Pimm SL, Russell GJ, Gittlema JL, Brooks TM (1995) The future of biodiversity. Science 269:347-350

Ruiz PM, Arnold, JEM (1996) Current issues in non-timber forest products research. Proceedings of the Workshop Research on NTFP. Hot Springs, Zimbabwe 28 August-2 September 1995. CIFOR. ODA. Indonesia

Roberts L (2011) 9 billion? Science 333:540-543

Sedell J, Sharpe M, Apple DD, Copenhagen M, Furniss M (2000) Water and the U.S. Forest Service. USDA, U.S. Forest Service

UNEP-WCMC (1998). Global generalised 'original' forest dataset (V 1.0) prepared at UNEP World Conservation Monitoring Centre, March 1998. http://old.unep-wcmc.org/medialibrary/2011/09/27/ 05ccdaa3/ofc_cfc_gen.pdf. Accessed 27 December 2015

United Nations World Water Assessment Programme (2014) The United Nations world water development report 2014: vol 1. Water and energy. Paris, France; UNESCO. http://unesdoc. unesco.org/images/0022/002257/225741E.pdf. Accessed 8 July 2015

United Nations World Water Assessment Programme (2015) The United Nations world water development report 2015: water for a sustainable world. Paris, France; UNESCO

U.S. Congress (1897) Organic Act of 1897 [public No. 2]. http://www.cfr. washington.edu/classes.esrm.459/yellowstone/yellowstone/ Project1/Yellowstone_Docs/ORGANIC\%20ACT\%20OF\% 201897.pdf. Accessed 28 December 2015 
U.S. Department of Energy (2013) A brief history of coal use. http:// www.fossil.energy.gov/education/energylessons/coal/coal_history. html. Accessed 28 December 2015

U.S. Energy Information Administration (2015) Today in energy, April 22, 2015. http://www.eia.gov/todayinenergy/detail.cfm?id=20912. Accessed 8 July 2015
USDA Forest Service (2011) Strategic energy framework. http://www.fs. fed.us/specialuses/documents/Signed_StrategicEnergy_ Framework_01_14_11.pdf. Accessed 8 July 2015

USDA, National Agroforestry Center (2015) Forest farming. http://nac. unl.edu/practices/forestfarming.htm. Accessed 19 June 2015

Waring RH, Schlesinger WH (1985) Forest ecosystems, concepts and management. Academic, London 